\title{
Werner DELFMANN
}

\section{HOW SUPPLY CHAIN MANAGEMENT CAN CONTRIBUTE TO EUROPEAN INTEGRATION?}

The author wants to discuss how the dynamics of global value chains and the implementation of the concept of Supply Chain Management impact the process of European Integration. Not only the Economic Integration. He wants to explicate that and how this impact goes further into the domains of social and even cultural integration. While Value Chain research has a strong economic focus, including international trade and developing countries issues (Kaplinsky, 2004), Supply Chain Management, SCM is focused on the individual company level, vertical co-operation and corporate strategy. Both perspectives are inseparably intertwined. However, with the following reflections he wants to emphasise the inter-company perspective of SCM. In explicating the conceptual alternatives of SCM, SC Governance and their dynamics in a general way, he wants to lay the groundwork for the final conclusions regarding the potential impacts of SCM on European Integration.*

European integration and European cooperation is very high on the political agenda in most European countries. The European question is already deeply imbedded in our public life, in our culture and in our everyday life. The strong emotional reactions pro and against questions of European integration and to globalisation as such are however an indication of existing challenges and problems. We still live and think very much as local and national citizens and not as European and global citizens. Globalisation of supply chains has taken place, but we still see the global environment from our national and local perspective. This makes the project of European integration complex. The discussion about opportunities and risks of going European has gained new intensity through the current debate about the European constitution and the situation in the recently enlarged European Union, facing further enlargement in the future.

Most of the expectations regarding the benefits of integration have always been based on the concept of an open European market. However, such expectations have also always been contrasted by the reluctance against EU bureaucracy and centralism, which is fully understandable in the light of European diversity. Against this background the EU Summit at Lisbon in March 2000 was an important mark on the way to a deeper European integration. EU prime ministers announced the adoption of 'a new open method of coordination', which is based on benchmarking and spreading best practice. It is intended to help memberstates converge towards common objectives in areas such as employment, economic reform and social cohesion. It is supposed to enable member-states to co-operate closely, yet recognises their diversity and avoids forced harmonisation and allows for a concerted EU approach while leaving legal competence and authority with the individual memberstates. (Goetschy, 2003; Hughes, 2000/1).

It remains to be seen whether open co-ordination can boost the EU's progress towards a competitive,

\footnotetext{
* Slightly amended version of the author's inaugural lecture on the occasion of the doctor honoris causa ceremony at CORVINUS University, Budapest, on November 22, 2004.
} 
knowledge-based economy. But it is a fact that this method has allowed the EU to extend the concept of joint action into new policy areas. The OMC provides a fully decentralized approach in line with the Principle of Subsidiarity (Calliess, 1999) in which the Union, the Members States, the regional and local levels, as well as the social partners and the civil society, will be actively involved, using variable forms of partnership.

Focussing our analysis on the potentials of European Economic Integration we have to consider that there is a strong interrelationship between national or regional and private company related issues in the $\mathrm{EU}$, and to discuss economic and business issues in the EU context has to take into account the fact that European markets develop as part of the bigger global economy and market trends. (Baldwin - Wyplosz, 2004; Döhrn, 1998/9; Faust - Voßkamp - Wittke, 2004; Potratz - Widmaier, 1998/9; Ruiz Jimenez et al., 2004).

\section{Supply Chain Management:}

\section{An approach to integrate (global) value chains}

A supply chain is commonly regarded as a multilevel sequence of material suppliers, production facilities, distribution services and customers which are linked together by the flow of goods and information (Towill - Naim - Wikner, 1992). And Supply Chain Management aims at the systemic, strategic coordination of the whole SC (Mentzer et al.,
2001). In the global context SC Integration can even be seen as the main distinction between internationalisation and globalisation (Dicken, 1999). Simplified we can say that SCM configuration and coordination of vertical value chains, especially their vertical integration versus disintegration on the strategic as well as the operative level. In other words: The fundamental question of SCM is: What are the key influence factors and alternatives for SC Governance? Which are the general principles for the organisation and coordination of vertical value chains? And who are the governors conducting that? (Figure 1.)

Regarding these key questions some general characteristics of a common ("orthodox") vision have begun to appear over the last years with all signs pointing to a supply chain built around compressed cycle times, increased information flows and focal control by the most powerful actor in the chain ("dominated SC") (Jackson - Winkler). However, this view of the supply chain's future may be ,utopian". Is the idea of planning across the extended enterprise akin to the dreams of totally planned economies? Will supply chains ever be able to function as harmonious, unified entities? Companies may give lip service to the idea of shared goals and shared profit, but ultimately they will behave independently, in their own perceived best interests and in pursuit of their own goals. For example companies may not be willing to share information that they view as potentially giving them some competitive advantage.

Facing these challenges a different approach has been proposed only recently. This does not mean to

Figure 1

Generic Supply Chain. Source: Delfmann, W. (1998)

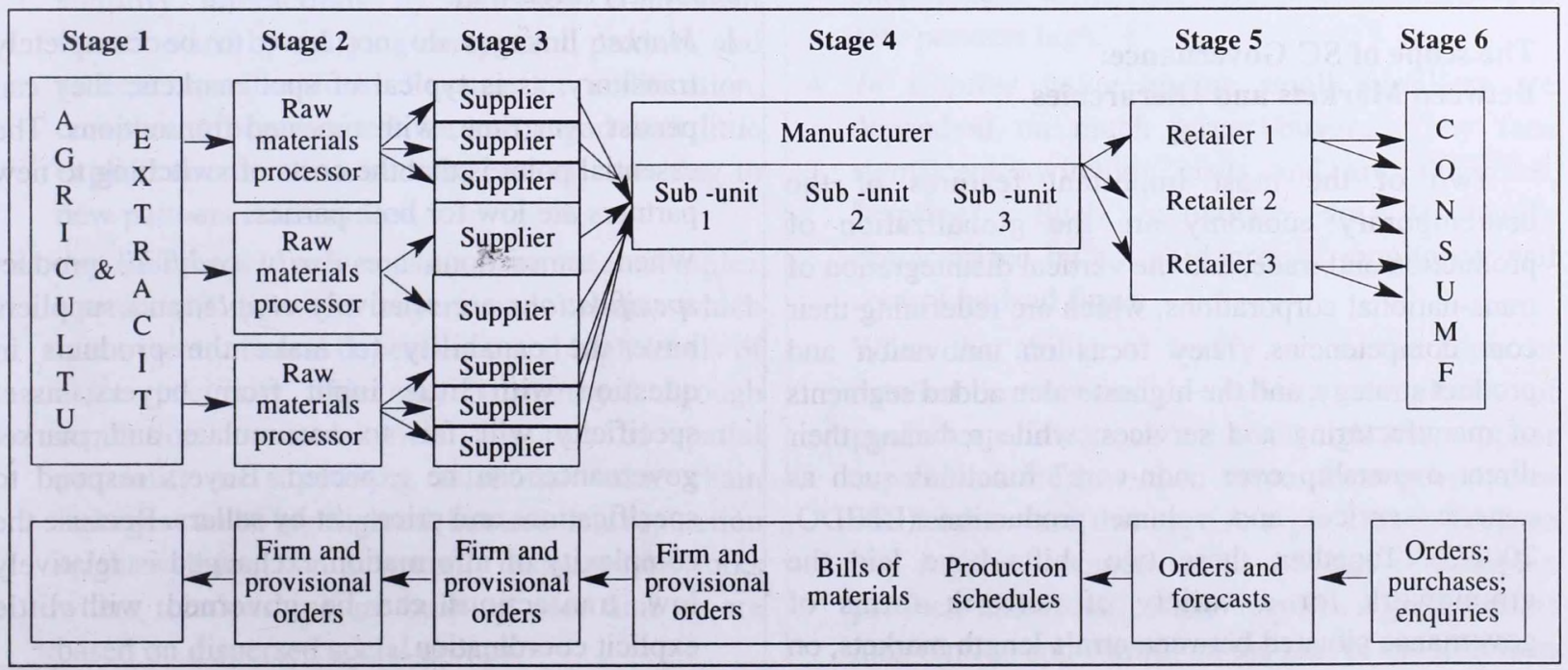


give up the idea of SC integration. But the approach follows a different paradigm. Interestingly enough this concept is fully in line with the above mentioned OMC on the political level. A "federated SC" is a system in which each member continues to act independently in pursuit of its own goals and on behalf of its own shareholders, much like members of a political federation pursue their own policies on behalf of their citizens (Reese, 2001; Ulrich; Zuboff - Maxmin, 2002). Through ongoing dialog, supply chain partners can understand critical constraints and cost drivers in the supply network and achieve agreement on performance levels, incentives, rules and boundaries. These boundaries define supply policies and targets and govern the flow of information across organizations.

Advocates of the federated model assert that it is less complex and more efficient than the „utopian approach." Over time, the theory goes, supply chains will become increasingly efficient as companies swap trading partners in response to perceived potential gains in efficiency or to changes in market conditions. The federated approach also allows companies to think about how they can change existing products to take advantage of new technologies or new suppliers that offer innovative ways to solve a design problem in an existing product, since this model provides for the relatively easy switching of suppliers in and out of a supply chain. But - as on the political stage we can ask: Is this another utopian idea - only on the other side of the scale? Obviously there is no simple answer. What we have to understand is the contingencies under which different forms of supply chain governance can be appropriate (Gereffi - Humphrey - Sturgeon, 2004; Palpacuer, 2000).

\section{The scope of SC Governance:}

\section{Between Markets and Hierarchies}

Two of the most important features of the contemporary economy are the globalization of production and trade, and the vertical disintegration of trans-national corporations, which are redefining their core competencies. They focus on innovation and product strategy, and the highest value added segments of manufacturing and services, while reducing their direct ownership over ,non-core" functions such as generic services and volume production (UNIDO, 2002/3). Together, these two shifts have laid the groundwork for a variety of network forms of governance situated between arm's length markets, on the one hand, and large vertically integrated corporations, on the other. The evolution of globalscale industrial organization affects not only the fortunes of firms and the structure of industries, but also how and why countries advance - or fail to advance - in the global economy. Global value chain research examines the different ways in which global production and distribution systems are integrated, and the possibilities for firms - and countries - to enhance their position in global markets (Wood, 2001).

Production in different countries leads to crossborder production networks within or between firms. This ,disintegration of production" in the global economy has led to a growing proportion of international trade occurring in components and other intermediate goods. There is a broad theoretical basis for the development of a range of vertical network-like arrangements. They can be explained from a Transaction Cost Perspective (Williamson, 1975) and through Network Theory (Thorelli, 1986); Jarillo (1988); Powell (1990) as well as through literature on Firm Capabilities (Penrose, 1959) and Organisational Learning and the Concept of Core Competences (Prahalad - Hamel, 1990). These considerations lead to a differentiated typology of value-chain governance. And we can explicate under which conditions different types of global value chain governance should arise by analysing three key determinants of value chain governance patterns: complexity of transactions, codification of information and capability of supplier. These three factors directly impact the choice of value chain governance. We can briefly distinguish five types of governance (Gereffi - Humphrey - Sturgeon, 2003, 4ff) (Figure 2):

1. Market linkages do not have to be completely transitory, as is typical of spot markets; they can persist over time, with repeated transactions. The essential point is that the costs of switching to new partners are low for both parties.

When transactions are easily codified, product specifications are relatively simple, and suppliers have the capability to make the products in question with little input from buyers, asset specificity will fail to accumulate and market governance can be expected. Buyers respond to specifications and prices set by sellers. Because the complexity of information exchanged is relatively low, transactions can be governed with little explicit coordination. 
Types of Supply Chain Governance. Source: Gereffi - Humphrey - Sturgeon (2003: 9.p.)

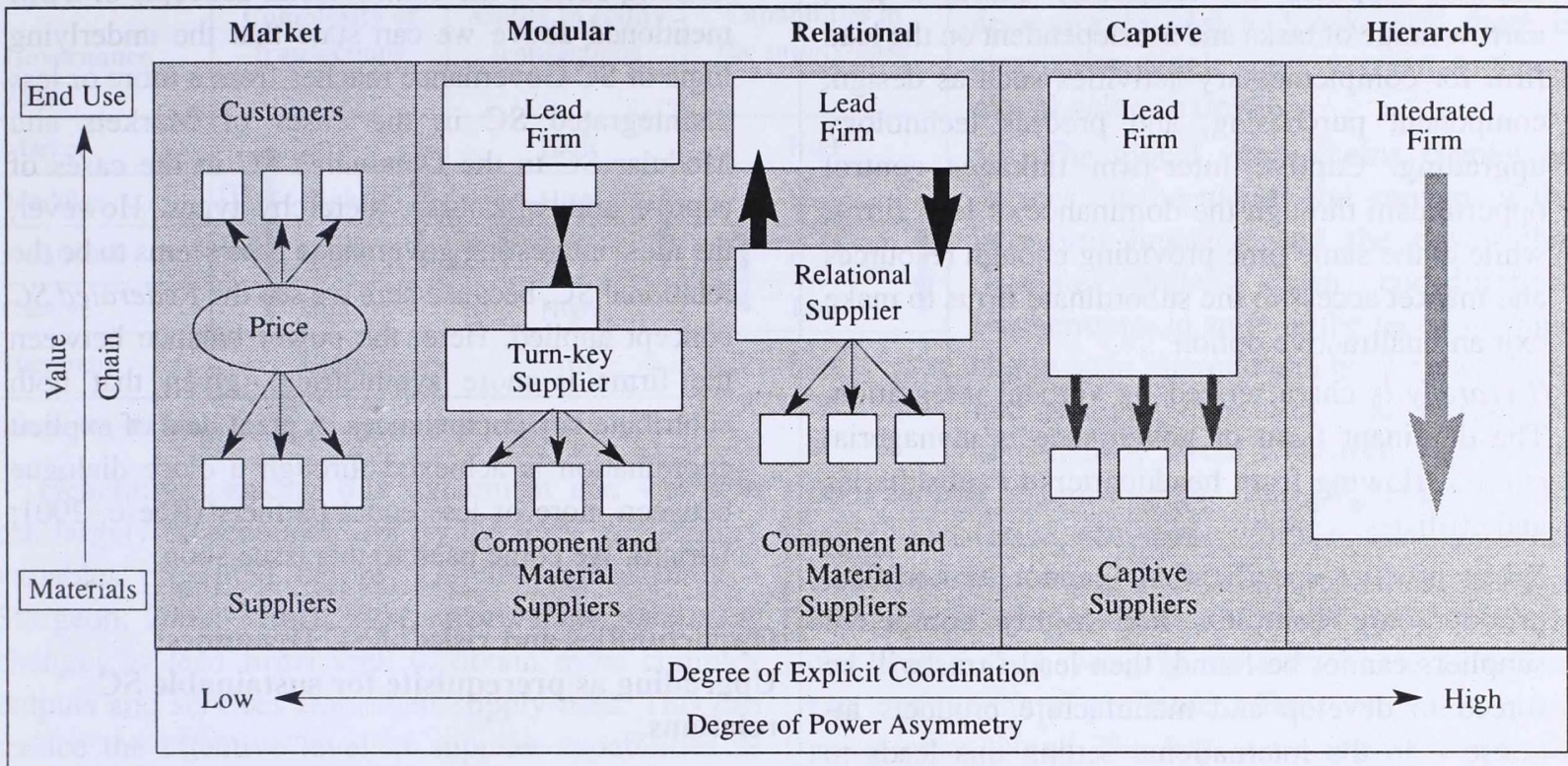

2. Typically, suppliers in Modular value chains make products to a customer's specifications, which may be more or less detailed. However, „turn-key services" suppliers take full responsibility for competencies surrounding process technology, use generic machinery that limits transaction specific investments, and make capital outlays for components and materials on behalf of customers.

When the ability to codify specifications extends to complex products, value chain modularity can arise. This can come about when product architecture is modular and technical standards simplify interactions by reducing component variation and by unifying component, product, and process specifications. Because of codification, complex information can be exchanged with little explicit coordination, and the cost of switching to new partners remains low.

3. In Relational value chains we see complex interactions between buyers and sellers, which often create mutual dependence and high levels of asset specificity. This may be managed through reputation, or social ties. The role of spatial proximity in supporting relational value chain linkages can be highlighted, but trust and reputation might well function in spatially dispersed networks where relationships are built-up over time or are based on dispersed social groups.
When product specifications cannot be codified, transactions are complex, and supplier capabilities are high, relational value chain governance can be expected. This is because tacit knowledge must be exchanged between buyers and sellers, and because highly competent suppliers provide a strong motivation for lead firms to outsource to gain access to complementary competencies. The mutual dependence can also be handled through credible commitments. The exchange of complex tacit information is accomplished by frequent interaction and governed by high levels of explicit coordination, which makes the costs of switching to new partners high.

4. In Captive value chains small suppliers are dependent on much larger buyers. They face significant switching costs and are, therefore, "captive". Such networks are frequently characterized by a high degree of monitoring and control by lead firms.

When the ability to codify - in the form of detailed instructions - and the complexity of product specifications are both high but supplier capabilities are low, then value chain governance will tend toward this captive type. This is because low supplier competence in the face of complex products and specifications requires a great deal of intervention and control on the part of the lead firm 
which seeks to lock-in suppliers in order to exclude others from reaping the benefits of their efforts. Captive suppliers are frequently confined to a narrow range of tasks and are dependent on the lead firm for complementary activities such as design, component purchasing, and process technology upgrading. Captive inter-firm linkages control opportunism through the dominance of lead firms, while at the same time providing enough resources and market access to the subordinate firms to make exit an unattractive option.

5. Hierarchy is characterized by vertical integration. The dominant form of governance is managerial control, flowing from headquarters to subsidiaries and affiliates.

When product specifications cannot be codified, products are complex, and highly competent suppliers cannot be found, then lead firms will be forced to develop and manufacture products inhouse - in the international setting this leads to Foreign Direct Investment. This governance form is usually driven by the need to exchange tacit knowledge between value chain activities as well as the need to effectively manage complex webs of inputs and outputs and to control resources, especially intellectual property. (Figure 3)

Each of these 5 governance types provides a different trade-off between the benefits and risks of vertical (dis-) integration. They comprise a spectrum running from low levels of explicit coordination and power asymmetry between buyers and suppliers, in the case of markets, to high levels of explicit coordination and power asymmetry between buyers and suppliers, in the case of hierarchy. The fact that the governance types developed here can be used to illuminate how power operates in global value chains merits elaboration. Coming back to the controversial concepts of SCM mentioned above we can state that the underlying logic of SC Governance reaches from a more or less disintegrated SC in the cases of Markets and Modular SC to the Dominated SC in the cases of captive and, of course, hierarchy types. However, the most interesting governance type seems to be the relational SC, because here we see the Federated SC concept applied. Here, the power balance between the firms is more symmetrical, given that both contribute key competences. A great deal of explicit coordination is achieved through a close dialogue between more or less equal partners (Reese, 2001; Ulrich). We come back to this issue soon.

\section{Opportunities and risks of SC Dynamics: Upgrading as prerequisite for sustainable SC relations}

Value chain configuration and governance are not static or strictly associated with particular industries. The supply chain train keeps on rolling continuously. And there are many examples proving especially that companies - and regions or countries - mainly relying on low labour-cost could only temporarily profit from such an advantage. One such case is Mexico, which has lost its low cost position regarding the US market to South East Asian countries and not really built up a sustainable competitive position based on capabilities. And this is of course also a major risk for European companies, where the low cost train will be rolling further to the East. Ireland, on the other side, is an excellent example of a country which has successfully upgraded its position in international value chains significantly.

Figure 3:

Characterictics of Supply Chain Governance Types.

\begin{tabular}{|l|c|c|c|c|}
\hline $\begin{array}{l}\text { Governance } \\
\text { Type }\end{array}$ & $\begin{array}{c}\text { Complexity of } \\
\text { transactions }\end{array}$ & $\begin{array}{c}\text { Ability to codify } \\
\text { transactions }\end{array}$ & $\begin{array}{c}\text { Capabilities in } \\
\text { the supply-base }\end{array}$ & $\begin{array}{c}\text { Degree of explicit } \\
\text { coordination and } \\
\text { power asymmetry }\end{array}$ \\
\hline Market & Low & High & High \\
\hline Modular & High & High & High \\
\hline Relational & High & Low & High \\
\hline Captive & High & High & Low \\
\hline Hierarchy & High & Low & Low & High \\
\hline
\end{tabular}

Source: Gereffi - Humphrey - Sturgeon (2003: 8.p.) 


\section{Dynamics of Supply Chain Governance}

\begin{tabular}{|c|c|c|c|}
\hline $\begin{array}{l}\text { Governance } \\
\text { Type }\end{array}$ & $\begin{array}{l}\text { Complexity of } \\
\text { transactions }\end{array}$ & $\begin{array}{l}\text { Ability to codify } \\
\text { transactions }\end{array}$ & $\begin{array}{l}\text { Capabilities in } \\
\text { the supply-base }\end{array}$ \\
\hline Market & Low & High & High \\
\hline Modular & High 2 & 1 High 4 & High \\
\hline Relational & High & 31 Low & High 6 \\
\hline Captive & High & High & Low \\
\hline Hierarchy & High & Low & Low \\
\hline
\end{tabular}

Source: Gereffi - Humphrey - Sturgeon (2003: 11.p.)

Generally speaking this dynamism and variation can largely be accounted for by the three explanatory variables presented before (Gereffi - Humphrey Sturgeon, 2003: 11.p.). First, information complexity changes as lead firms seek to obtain more complex outputs and services from their supply-base. This can reduce the effective level of supplier capabilities as existing capabilities may not meet the new requirements (trajectory number 1 in figure 4 ). Alternatively, reduced complexity may increase the ability to codify transactions (trajectory 2 in figure 4 ). Second, within industries there is a continuing tension between codification and innovation (trajectories number 3 and 4 in figure 4). New technologies can restart the clock on the process of codification. Third, supplier competence changes over time: increasing as suppliers learn, but falling again as buyers introduce new suppliers into the value chain, as new technologies come on-stream, or as lead firms increase the requirements for existing suppliers (trajectories number 5 and 6 in figure 4).

Increasing capabilities in the supply-base helps to push the architecture of global value chains away from hierarchy and captive networks and toward the relational, modular, and market types.

Value chain modularity seems to be especially likely when suppliers offer lead firms greater levels of value chain bundling (e.g., turn-key and full-package services), which has the advantages of internalizing tacit knowledge and pooling capacity utilization for greater economies of scale. As standards, information technology, and the capabilities of suppliers improve, the modular form appears to be playing an increasingly central role in the global economy. When we take relational networks as our starting point, however, a shift to modular - and perhaps eventually to market -
Figure 4: forms can be expected as standards and codification schemes improve because more fluid value chains offer additional decreases in cost and risk. Still there is clearly no single best way to organize global value chains.

The global value chains framework focuses on the nature and content of the inter-firm linkages, and the power that regulates value chain coordination. Furthermore, in spite of the fact that value chains span international borderlines, local and national structures and institutions also matter. Local industrial agglomerations support organisationally disaggregated, and often highly innovative, economic activities and the spatial embeddedness of tacit knowledge and the importance of tight interdependencies between geographically clustered firms have to be stressed. These variations can and do have profound effects on value chain governance. Now: The key issue arising from this analysis is how producers - whether firms, regions or countries -should or can participate in global value chains. There are two paths of insertion. The low road is one of immiserizing growth, a trajectory in which producers face intense competition and are engaged in a „race to the bottom". By contrast, those who exhibit the ability to enter a virtuous circle of participation in the global economy may realize more sustained income growth.

What explains the difference between these two paths is the capability to innovate, and to ensure continuous improvement in product and process development. If this is the case, then the emphasis needs to be placed on the ability to learn and this has implications not just for the productive sector itself, but also for the whole national system of innovation. Of course this capability to innovate has to be placed in a relative context, compared to competitors, and this process can be referred to as one of Upgrading (Kaplinsky - Readman, 2001: 27ff; Humphrey Schmitz, 2000).

The issue of upgrading ore - more general - of organisational learning - has been addressed in recent years mainly by two related theories, which have already been mentioned. The first has focused on core competences (Hamel - Pralahad, 1994; Leonard Barton, 1995), the second on dynamic capabilities (Teece-Pisano, 1994). The latter argues that corporate profitability in the long run cannot be sustained by 
control over the market (for example, through the adoption of quasi-monopolistic practices), but through the development of dynamic capabilities which arise as a result of the firm's internal processes which facilitate learning. This relates both to the achievement of new product and process development, and in the functional reconfiguration of who does what in the chain as a whole. Firms can adopt four trajectories in pursuing the objective of upgrading, namely (Kaplinsky - Readman, 2001: 30ff):

- Process upgrading: Increasing the efficiency of internal processes, both within individual links in the chain (for example, increased inventory turns, lower scrap), and between the links in the chain (for example, more frequent, smaller and on-time deliveries).

- Product upgrading: Introducing new products or improving old products faster than rivals. This involves changing new product development processes both within individual links in the value chain and in the relationship between different links of the chain.

- Functional upgrading: increasing value-added by changing the mix of activities conducted within the firm or moving the focus of activities to different links in the value chain (for example from manufacturing to design).

- Chain upgrading: moving to a new value chain (for example, Taiwanese firms moved from the manufacture of transistor radios to calculators, to TVs, to computer monitors, to laptops and now to WAP phones).

Firms are challenged to not only target a positive financial surplus, but to also aim to achieve minimum quality, environmental, and social standards which are becoming an increasingly important qualifying requirement for participation in global product markets and global value chains (Allen, 2004; Bank Jörgensen - Nielsen; Ponte, 2004). As this is a dynamic development, the capacity to meet this changing agenda of standards is emerging as an increasingly important category of process upgrading. Understanding the interrelationship between the dynamics of global value chain governance, and the upgrading capability of companies clearly allows deriving useful insights for developing sustainable supply chain relationships.

\section{Conclusion: Federated Value Chains as a contribution to European Integration}

And here we come back to the issue of European integration on the inter-company level. What are our conclusions regarding the challenges and opportunities companies face in Europe, especially in the new member states of the European Union as well as in future accession states. How can they prepare for sustainable competitiveness in the light of global value chain dynamics and hereby gain, retain and develop favourable value chain positions?

Taking our analysis regarding the different types of value chain governance as a reference and assessing the respective position especially on the supplier side, a clear message can be derived. There are of course business potentials in all types of value chains, but when it comes to develop a sustainable position there is an obvious favourite: Creating conditions to establish relational supply chains through continuously building up capabilities and competences which enable companies to be equal supply chain partners, not easily to be exchanged, creating mutual benefits as well as mutual dependence. And especially in the European context it makes much sense to develop or improve such capabilities on the basis of the existing regional, economic, technical and cultural diversity in Europe. Because this is exactly the complementarity needed for relational Supply Chains and this creates the conditions to build up Federated Supply Chains. It allows overcoming the inherent risks of being locked-in under the control of a dominant lead-company on one side or being highly vulnerable and under continuous pressure in a low cost competition for simple, mass products on the other side. And clearly: the quality of integration is completely different. Federated supply chains have the character of vertical alliances (Anderson, 2000; Rinehart, 1992), based on voluntary co-operation of equal partners, acknowledging diversity and complementarity of capabilities and herewith creating additional benefits for all actors involved which could otherwise not be achieved.

This is obviously an optimistic model of European economic integration, but it is not utopian, it is achievable. And it is truly aiming at implementing the idea of a sustainable European integration - including the social and cultural integration. 


\section{Literature}

Allen, J. (2004): Responsible Value Chain: What are you accountable for? In: Annual meeting 2004, Governors of the world economic forum for food, beverage, retail and consumer goods. World Economic Forum, Davos, 1-5.

Anderson, G. (2000): From Supply Chain to collaborative Commerce networks: The next step in supply chain management, Ascet 2.

Baldwin, R. E. - Ch. Wyplosz (2004): The Economics of European Integration, Berkshire

Bank Jörgensen, H. - A. Nielsen: Development of monitoring systems and reporting on compliance with code of conduct throughout the supply chain. http://www.pwc.com/extweb/ pwcpublications.nsf/docid/91D199F0064111CC80256A7F00 3B2DC6?OpenDocument

Calliess, Ch. (1999): Subsidiaritäts- und Solidaritäsprinzip in der Europäischen Union, Vorgaben für die Anwendung von Art. 5 EGV nach dem Vertrag von Amsterdam, Schriften des EuropaInstituts der Universität des Saarlandes- Rechtswissenschaft, 2. Auflage

Commission of the European Communities (2001): European Governance. A White Paper. Brussels

Cooper, J. C. (1993): Logistics Strategies for Global Business. International. Journal of Physical Distribution \& Logistics management, 23 (4), 12-23.

Delfmann, W. (1998): Organisation globaler Versorgungsketten, in: Glaser, H.; E. F. Schröder; A. von Werder(Hrsg.): Organisationen im Wandel der Märkte. Wiesbaden, 61-89.

Delfmann, W.; S. Albers (2000): Supply Chain Management in the Global Context. Working Paper No. 102, Department of Business Planning and Logistics, Köln

Dicken, P. (1998): Global Shift - Transforming the World Economy, 3rd Edition, London.

Dicken, C. - P. Kelly - K. Odds - H.W. - C. Yeung (2001): Chains and networks, territories and scales: towards a relational framework for analysing the global economy.Gobal Networks 1 (2), 89-112.

Döhrn, R. (1998/9): The new trade structure between East and West: Is integration already a matter of fact? in: Potratz / Widmaier (1998/9, 47-58.

Faust, M. - U. Voskamp - V. Wittke (eds.) (2004): European restructuring in a global economy: Fragmentation and relocation of value chains. SOFI Berichte, Göttingen

Ferrer, J. - Ch. Findlay (2003): European supply Chain management characteristics and challenges. Ascet 5.

Gereffi, G. -J. Humphrey - T. Sturgeon (2004): The governance of global value chains, forthcoming. Review of International Political Economy

Gnirke, K. (1998): Internationales Logistikmanagement. Strategische Entwicklung und organisatorische Gliederung der Logistik transnationaler Produktionsnetzwerke. Wiesbaden

Goetschy, J. (2003): The open method of coordination and EU integration. Institutionelle Strukturen und Finanzierung der EU. Fachhochschul-Fernstudienverbund der Länder Berlin Brandenburg Mecklenburg-Vorpommern Sachsen SachsenAnhalt Thüringen. 1. Auflage

Hamel, G. - C. K. Pralahad (1994): Competing for the Future, Cambridge, Mass.: Harvard Business School Press

Henderson, J. - P. Dicken - M. Hess - N. Coe - H.W. - C. Yeung (2002): Global production networks and the analysis of economic development. Review of International Political Economy 9 (3), 436-510.
Hughes, K. (2000/1): The Open Method of Co-ordination: Innovation or talking shop? CER Bulletin, issue 15, December 2000/ January 2001.

Humphrey, J. - H. Schmitz (2000): Governance and Upgrading in Global Value Chains. A Background Paper for the Bellagion Value Chain Workshop, Institute of Development Studies, University of Sussex, Brighton, UK.

Iyer, K. (2002): " Learning in Strategic Alliances: An Evolutionary Perspective." Academy of Marketing Science Review [Online] (10), http://www.amsreview.org/articles/iyer10-2002.pdf

Jackson, B.; C. Winkler: Building the Advantaged Supply Network. http://www.strategy-business.com/media/file/resilience09-15-04.pdf

Jarillo, J. (1988): On strategic networks. Strategic Management Journal 9 (1), 31-41.

Kaplinsky, R. - J. Readman (2001): Integrating SMEs in global value chains. Towards partnership for development. United Nations Industrial Development Organisation, Vienna

Langlois, R.. - P. Robertson (1995): Firms, markets and economic change, London, Routledge

Leonard-Barton, D. (1995): Wellsprings of Knowledge, Cam bridge, Mass.: Harvard Business School Press

Mentzer et al. (2001): Defining Supply Chain Management Journal of Business Logistics, 22(2).

Palpacuer, F. (2000): Characterising Governance in Value Chain Analysis. IDS / Rockefeller Foundation Meeting on Global Value Chains, Bellagio, Italy, September 25 - October 2

Penrose, E. (1959): The theory of the growth of the firm, Oxford.

Ponte, St. (2004): Quality Conventions and the Governance of Global Value Chains. Research Paper, Danish Institute for International Studies, Copenhagen

Potratz, W. - B. Widmaier (eds.) (1998/9): East European Integration and New Division of Labour in Europe, Workshop Documentation. Graue Reihe des Instituts Arbeit und Technik, Gelsenkirchen

Potratz, W. - B. Widmaier (1998/9): European Integration: The difficult balance between traditional institutions and new demands, in: Potratz / Widmaier (1998/9, 25-34.

Powell,W. (1990): Neither market nor hierarchy: network forms of organization. Research in Organizational Behaviour 12, 295336.

Prahalad, C. - G. Hamel (1990): The core competence of the corporation. Harvard Business Review 68 (3), 79-91.

Reese, A. K. (2001): Supply chains: the next generation. iSource Business, October 2001.

Reid, G. C.: Free trade, business strategy and globalization. http://www.st-andrews.ac.uk/crieff/papers/dp0009.pdf

Rinehart, L.M. (1992): Global Logistics Partnership Negotiation. International Journal of Physical Distribution \& Logistics Management, 22 (1), 27-34.

Ruiz Jiménez, A. M.. - J. J. Górniak - A. Kosic - P. Kiss - M. Kandulla (2004): European and National Identities in EU's Old and New Member States: Ethnic, Civic, Instrumental and Symbolic Components. European Integration online Papers (EIoP) 8 (11), http://eiop.or.at/eiop/texte/2004-011a.htm

Sturgeon, T. (2002): Modular production networks: a new American model of industrial organization. Industrial and corporate change 11 (3), 451-496.

Sturgeon, T. - R. Flodida (2004): Gobalization, deverticalization and employment in the motor vehicle industry, in: M. Kenney and P. Kogut (eds.): Creating Global Advantage, Stanford, CA.

Teece, D. - G. Pisano (1994): „The Dynamic Capabilities of Firms: An Introduction", Industrial and Corporate Change, 3, 537-556. 
Thorelli, H. (1986): Networks: between markets and hierarchies. Strategic Management Journal 7, 37-51.

Towill, D. R. - M. M. Naim. - J. Wikner, (1992). Industrial dynamics simulation models in the design of supply chains. International Journal of Physical Distribution and Logistics Management, 22(5), 3-13.

Ulrich, W.: Revolutionizing supply chain management through. holistic governance structures. http://www.systemtransformation.com/Org_Transformation_Articles/org_supply.htm

UNIDO Report (2002/2003): Competing through innovation and learning, http://www.unido.org/doc/24397

Wood, A. (2001): Value chains: an economists perspective. IDS Bulletin, 32 (3).
Yamawaki, H. (2004): The Determinants of Geographic Configuration of Value Chain Activities:

Foreign Multinational Enterprises in Japanese Manufacturing. Paper presented at the "Economic Integration, Innovation Dynamics and Growth Workshop", Brussels, February 6-8, 2004. Forthcoming in Journal of International Economics and Economic Policy

Yanikkaya, H. (2003): Trade openness and economic growth: a cross-country empirical investigation. Journal of Development Economics 72, 57-89.

Zuboff, Sh. - J. Maxmin (2002): The Support Economy: Why Corporations are failing individuals and the next episode of capitalism. Viking Penguin 